stated in the introduction to the volume, the influence of omitted days was duly taken into account, values for such days being adopted from the eye observations (usually six daily) corrected for diurnal inequality by means of corrections derived from the discussion of the twenty years' photographs. Thus, among the twenty separate daily values on which each mean daily value in Table 77 depends, one or two may be derived from eye-observations in the way described.

The diurnal variation of temperature in the apartment in which the photographic barometer is placed is, on the average, less than one degree.

Royal Observatory, Greenwich, October 27

\section{Sun-Spots in Earnest}

WITH reference to the fine group of sun-spots to which Prof. Piazzi Smyth draws attention in NATURE, vol. xx, p. 602, it may be interesting to mention that the incipient stage of the group in enestion is shown on two photographs of the sun taken at the Royal Observatory, Greenwich, on October I6 (two days before the date of Prof. Piazzi Smyth's observation). At that time the group consisted of three "veiled" spots and several very small specks hardly to be distinguished from the ordinary pores, together with small faculæ. No photographs were obtained on the next day, and on October 18 enormous changes had taken place, the "veiled" spots having developed into fine sun-spots, with nucleus and penumbra. Four photographs taken on this day show that changes were still taking place, and these continued throughout the remainder of the period of visibility of the group, viz., till October $2 \mathrm{I}$, when it passed off at the west limb, No trace of the gromp is to be found on two photographs taken on October 15, so that it would appear to have formed between October 15 and 16 , and must have been quite in its infancy when first photographed on October 16 , being then very nearly on the central meridian.

Several small spots have appeared on the sun lately, but they have been for the most part very short.lived. Thus a group of spots with faculi, first seen on the east side of the sun on October 15, had completely disappeared on October I6. Another group consisting of six or seven small spots with faculæ, which appeared at the east Iimb on October 7 , had completely closed up in the interval between October Io and I5. On the whole the Green. wich photographs seem to support Prof. Piazzi Smyth's conclusion that the period of quiescence is now over, and that the solar activity is decidedly on the increase. W. H. M. CHRISTIE

Royal Observatory, Greenwich, October 25

THE Kew solar observations now are, unfortunately, limited to a daily inspection of the sun through a 3 -inch telescope, and the drawing of a rough sketch of the spots on its surface, should any be visible, the object the Committee lave in view being merely a continuation of the enumeration of the groups as they make -their appearance, in the same manner as did Hofrath Schwabe.

I have referred to the sketches drawn on the 15 th, I $6 \mathrm{th}, 17 \mathrm{th}$, and 18 th instants, in order to see what records they afford of the outbreak of the group of spots mentioned by Prof. Piazzi Smytin in NATURE, voli $x x, p, 602$, and find we noted on the $15^{\text {th }}$ two small spots in the sun's northern hemisphere. These were not seen on the 16 th, the disk being entered in the register as having "no spots," but at IO. 30 A. M. on the I 7th a group of small spots appeared to the south of the equator, just in the place occupied on the next day by the group of gigantic spots to which attention has been directed, allowance of course being made for the sun's rotation.

These observations show that the spots did not suddenly burst forth in their full grandeur, but that they broke through tree sun's surface gradually, that is to say, the explosion, if stich it was, extended over more than twenty-four hours.

In the examination of the Kew solar photograms from 1863 to 1872 now in progress here under the direction of $\mathrm{Mr}$. De la Rue, we have found several instances of similar extensive changes in spots from day to day, not only in the eruption of large spots, but also in their closing up in an equally short space of time.

To give more recent instances, I find that a considerable group of spots was observed on June 28 , of which we had no record on the $25^{\text {th }}$; and again, on July $x x$, some large spots were noted, whilst on the preceding day, July IO, "no spots" was entered in the register.

The magnetograph curves show a slight disturbance of the magnetic elements on the I 6 th and $I$ th, but during the 18 th the needle simply recorded its ordinary daily range.

I trust that better-equipped observers will be able to give you more exact accounts of this interesting phenomenon. The sunshine recorder here inclicated continuous sunshine on the 16 th, occasional gleams on the I 7 th, and seven hours on the 18 th, so the climate cannot be blamed for any shortcomings on the part of southern observers on this occasion. 'G. M. WHIIPPLE

Kew Observatory, October 25

THE conclusion as to the increasing activity of the solar surface, drawn by the Astronomer-Royal of Scotland from his observations of a large solar spot on the I8th instant, is strongly confirmed by the present state of the south-east quarters of the sun's dislk. Few prominences are now visible in the other portions of the limb, but on the 26th at $23^{\circ} \mathrm{IO} 0^{\prime} \mathrm{E}$. of the south point (direct image), the bright line $\mathrm{C}$ of the chromosphere extended to the height of $3^{\prime} 43^{\prime \prime}$ from the limb, and this morning, the 28 th, the greatest height was $I^{\prime} I 7^{\prime \prime}$ at $I 8^{\circ} 46^{\prime} \mathrm{E}$. of $\mathrm{S}$. On the 28 th the remarkable prominences extended along the linb from-

$\mathrm{r} 8^{\circ} 8^{\prime} \mathrm{E}$. of S. to $3^{\circ} \mathrm{E}$. of S.,

and this morning they were traced from$10^{\circ} 5 \mathrm{y}^{\prime} \mathrm{E}$. of $\mathrm{S}$, to $20^{\circ} 2 \mathrm{r}^{\prime}$

The ordinary level of the chromosphere does not extend above $5^{\prime \prime}$ from the limb, but to-day it was rather over $6^{\prime \prime}$.

Eight prisms of $60^{\circ}$ were used in a Browning automatic spec. troscope adapted to an 8-inch achromatic.

Stonyhurst Observatory, October 28

S. J. PERRY

\section{Wallace's "Australasia"}

ALLOw me to thank the writer of the review in NATURE, vol. xx. p. 597, for some valuable criticisms of my book. It is quite refreshing after the common-place praises of most reviews to have one's errors pointed out and omissions noticed, and I hope to make use of such corrections in a forthcoming new edition. At the same time there are a few points on which I wish to say a word. In the first place the book is not a scientific work, but one of a series intended, as expressly stated, "for" general reading." This is, of course, no excuse for errors, but it is a sufficient reason for giving general rather than detailed descriptions of weapons, canoes, \&c., and for occasionally stating roughly the size of an article even when it varies greatly, in order to give definite ideas to readers who may be complete strangers to the whole subject.

I quite agree with my reviewer, that too much is included to be properly treated in one volume, but that was a matter dependent on the arrangement of the series, over which I had no control; and as I had in the earlier portion of the work overrun the space allotted me, I was obliged to restrict my notices of many parts of Polynesia, which is no doutb the most imperfect portion of the volume. It is here that the original work is most utilised, and it will be found that most of the passages criticised (including that in which I am charged with "becoming quite poetical") are Hellwald's. Of course, I should have corrected all his small inaccuracies, but it was almost impossible to do so without rewriting his work altogether. No doubt a very interesting volume conld be written on Polynesia alone by the aid of the German authorities referred to by the reviewer; but when I state that the time allowed me for the composition of the entire work was six months, and that I actually completed it in eight, it will be seen that I was compelled to limit myself in the study of authorities as well as in the space I could devote to particular islands.

I think my reviewer forgets the character of the bools as essentially geographical, when he objects to my treating New Zealand apart from Polynesia; hence I cannot admit the soundness of his criticism on the comparison of the characters of the Fijians and Polynesians, a comparison which, if I remember riohtly, is that of an author who knew them both thoroughlythe Rev. G. Turner. I must also demur to the implication that land can never have extended where there is now a sea 2,000 fathoms deep. I suggest (p. 564) an extension of New Zealand as far as the Kermadec Islands as having possibly occurred "at some remote epocb," and I certainly fail to see its impossibility; yet this is what is suggested by my reviewer's remark, that unfortunately there is a depth of 2,000 fathoms between 